\title{
Research on Graduation Design Mode of Science and Engineering Undergraduates Based on Competitions
}

\author{
Xinming Huang ${ }^{1, *}$ Meiting $\mathrm{Yu}^{1}$ Jing Peng $^{1}$ Xiaohui Liu ${ }^{1}$ \\ ${ }^{1}$ College of Electronic Science and Technology, National Univ. of Defense Technology, Changsha, China \\ *Email: huangxinming_2007@163.com
}

\begin{abstract}
The graduation design of science and engineering undergraduates have characteristics of time-shorting and heavy tasks. How to improve the quality of undergraduate design is a major issue facing colleges and universities. An undergraduate graduation design model based on competition traction is proposed, and the engineering undergraduate graduation design link is disassembled into three parts: the experience competition stage, the sailing competition stage, and the graduation design stage. By decomposing the entire undergraduate graduation design link into each link of the university from an application point of view, it reduces the problem of difficult topic selection and enlightens students to choose the questions they are interested in, so as to improve the quality of the completion of the undergraduate graduation project. The undergraduate graduation design model proposed in this paper provides an effective way for the project-based research group to guide the undergraduate graduation design.
\end{abstract}

Keywords: Graduation Design Mode, Science and Engineering Undergraduates, Competition-driven, the experience competition stage, the sailing competition stage, undergraduate graduation design model

\section{INTRODUCTION}

The undergraduate graduation design is the final link of university undergraduate education. As an important part of the practical education link of the university, the main goal of the graduation design is to cultivate students' ability to comprehensively use the professional knowledge they have learned and analyze and solve problems. It is a test of the university's learning achievements [1]. The undergraduate graduation design work involves multiple subjects such as students, teachers, and schools. It seems to be a semester or academic year's work, but in fact it is closely related to the entire university stage of study, and it is a complex system engineering [2]. At present, the quality of undergraduate graduation project is very dependent on the teacher's personal experience and the students' own abilities. For example, teachers have a mature foundation, and the difficulty of undergraduate graduation design is reduced. Or the students have strong ability and can complete the graduation project well. If the teacher's selection of topics is too partial and the students have a relatively weak foundation in related aspects, the quality of the undergraduate graduation design will be low, and the phenomenon of "being left behind" in the graduate design will occur, and the link cannot be successfully completed. Especially for the teaching and scientific research projects, the undergraduate graduation design is often related to related scientific research projects. If the topic is improperly selected or the student's relevant foundation is too weak, its quality is more difficult to control. How to improve the quality of undergraduate graduation design, especially for research-oriented research groups, is an important issue that requires in-depth consideration.

\section{SITUATION ANALYSIS}

The teaching quality of graduation design (thesis) has received great attention within universities and the society in recent years. The overall quality of graduation design (thesis) in domestic colleges and universities has become an indisputable fact. It is even more difficult to do a good job in undergraduate graduation design [3] [4]. Combined with the implementation of some undergraduate graduation projects in our school, the main reasons for the decline in the quality of college graduation designs (thesis) are as follows: For instructors, undergraduate graduation design has increasingly become a task.

On the one hand, teachers have heavy research tasks and often do not have more energy to use undergraduate 
graduation design as the main task to guide and advance in a short time. More reasons are Without a good plan, and without understanding the students' learning ability and professional foundation, directly assigning part of the sub-topics of the scientific research project to the students often achieves poor results.

For students, the project is difficult to meet actual needs, time for graduation design is limited, and the enthusiasm for contact with new things decreases. When students are doing their undergraduate graduation project, they are approaching graduation, and there are many related graduation matters. For example, our school has more military training related to graduation, and students don't have more time to do more things. The graduation thesis is about 14 weeks long. If the time for reviewing the literature, writing the thesis and preparing for the defense is excluded, the time for students to actually do the graduation thesis is very limited [5].

There are more realistic reasons for universities that dominate research projects. The scientific research project involves many disciplines and requires a lot of knowledge reserves. If the topics in the scientific research project are directly used as the subject of the undergraduate graduation design, there are the following problems:

1) Students need to learn a lot of basic knowledge in advance, and the reserve of professional knowledge for university learning is not enough;

2) Students need to invest a lot of time, which greatly increases the difficulty of undergraduate graduation design;

3) The effect of the graduation design is not good. For a complex scientific research project, it is difficult for students to master it completely, and the effect for students' exercise is not good.

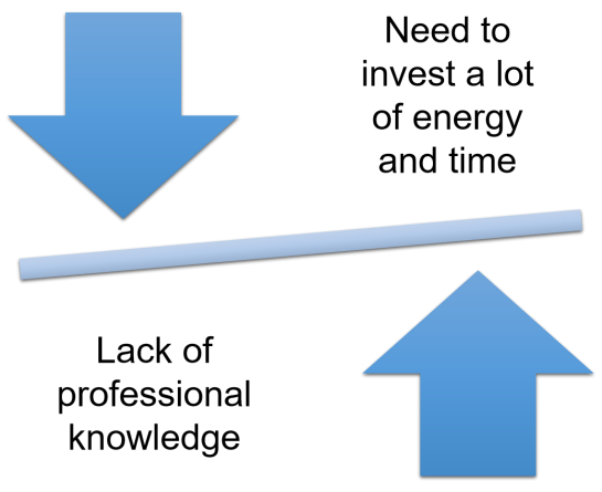

Figure 1 Problems of the undergraduate graduation design

Under the existing teaching model, students passively receive theoretical and experimental teaching in the classroom, and it is more difficult to enter the project topic selection in a passive learning state. How to achieve high-quality completion of undergraduate graduation design in scientific research projects is a big problem.

This article is based on the experience competition and sailing competition of the School of Electronic Science of National University of Defense Technology, combined with the undergraduate graduation design, to explore a new guidance and design method suitable for the undergraduate graduation project of the research group that undertakes more scientific research projects.

\section{COMPETITION-DRIVEN UNDERGRADUATE GRADUATION DESIGN MODEL}

Aiming at the short time and difficult problems in the undergraduate graduation design, the competitiondriven model is adopted to construct the undergraduate graduation design based on the competition model. Combining professional characteristics, following the law of learning growth of knowledge and abilities, carry out overall planning, and meet the diverse needs of students, the real needs of enterprises in content and form. Through the competition project link, the broad and profound professional theoretical knowledge mastered by students in theoretical teaching is used as an important weapon and tool for problem analysis and problem solving, so as to improve students' planning and decision-making ability in practice [6] [10]. The undergraduate graduation design model based on competition traction can be divided into three stages: the experience competition stage, the sailing competition stage, and the graduation design stage.

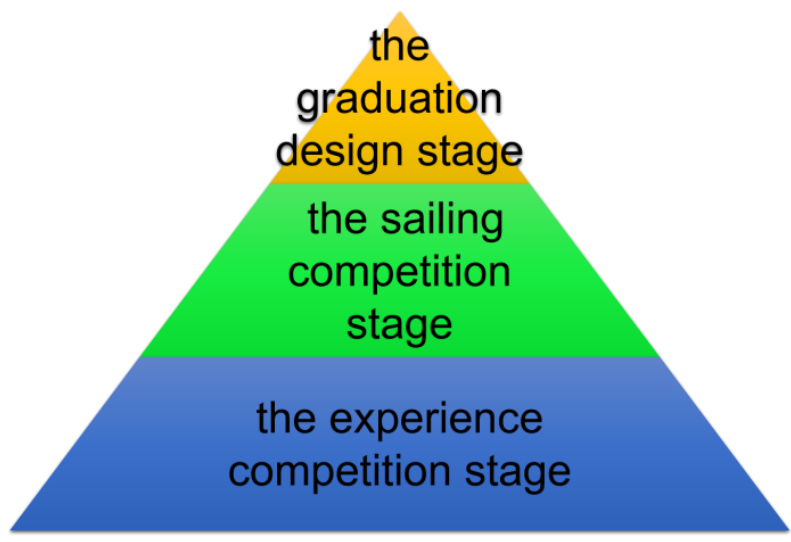

FIgure 2 Three parts of the undergraduate graduation design link

\subsection{The experience competition stage}

The experience competition stage is arranged in the freshman and sophomore stage. It is mainly for students to establish contact with teachers and have a preliminary understanding of the specific content involved in 
scientific research projects related to the undergraduate graduation design. According to the selection of the subject, the instructor will package the content of the relevant scientific research project as a whole, and by defining its function and purpose, let students understand its function and experience each application scenario, so as to understand it perceptually. Through the experience competition, students can truly understand the functions and definitions of the relevant equipment or system of the subject, so that they can have a deeper understanding of the purpose of the subject and the principles behind it. On the one hand, it allows students to understand this principle, on the other hand, it allows students to use this device to do some experiments to inspire students' thinking.

\subsection{The sailing competition stage}

The sailing competition stage is arranged in the second and third stages, allowing students to play their own subjective initiative and use corresponding equipment or systems to solve problems, so that students have a sense of innovation, and on the other hand, they also improve their abilities. Let students understand the working principle and shortcomings of this equipment or system.

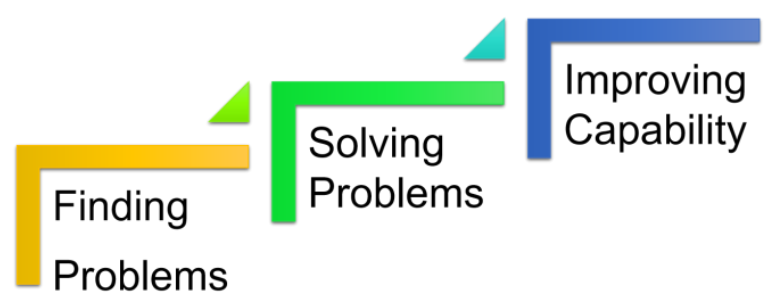

Figure 3 The sailing competition stage

\subsection{The graduation design stage}

The graduation design stage is arranged in the fourth stage, allowing students to find corresponding solutions according to their shortcomings, as the subject research of the undergraduate graduation design. This allows students to close the loop from problem discovery to problem solving, and improve their hands-on practical ability. Incorporating the whole process into the graduation design process of students, so that students can gradually understand the principles, apply the principles, improve the principles, and further innovate applications, which is also in line with the entire process of knowing things, understanding things, and innovating.

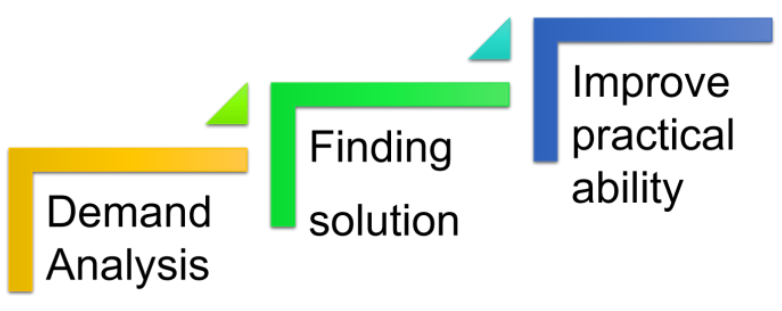

Figure 4 The graduation design stage

\subsection{Attention ans Benefits}

In this process, you need to pay special attention to the following points:

1) Make a step-by-step process without undue haste, so that students can learn from principles to experiments, and then innovative experiments.

2) Student initiative oriented: Gradually cultivate students' awareness of active learning and application, and students should not be allowed to receive passively without taking the initiative to act.

3) The increase in difficulty requires a progressive relationship, and there should be no sudden increase in difficulty.

4) Explore the team model, so that students can cultivate a spirit of collaboration, and find their own suitable parts, and gradually find out their own suitable theoretical innovation, application innovation, etc.

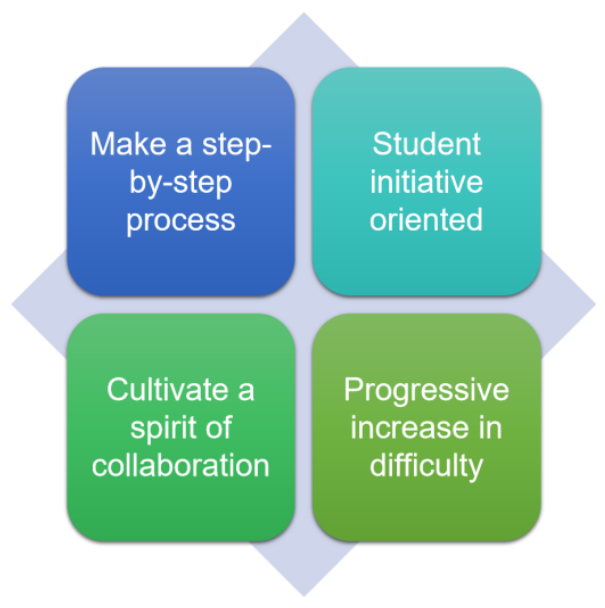

Figure 5 Attention points

The benefits of this approach are as follows:

1) It can allow students to accumulate, continue to learn, lay a good foundation, and form a virtuous circle, so that students can continue to innovate and give play to their initiative. 
2) Let the communication between teachers and students run through the students' college study career, improve the interaction between teachers and students, and form a virtuous circle.

3) In line with the current status quo, it can guarantee the quality of undergraduate graduation design with high quality, and it is more in line with the mode of cultivating students' innovative spirit.
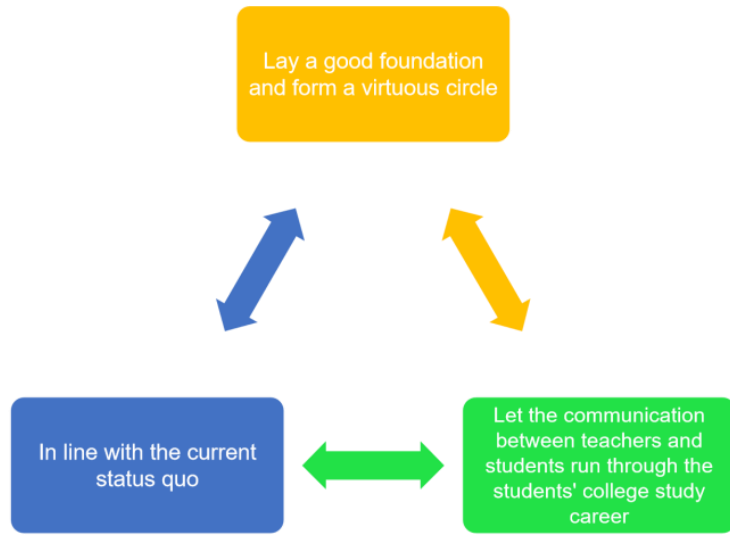

Figure 6 The benefits of the new approach

At present, according to this method, the author has trained several undergraduate graduation projects, and the practical effect is good.

\section{CONCLUSIONS}

This article proposes a competition-driven undergraduate graduation design model, which adopts the practice method of undergraduate graduation design combined with competitions, and decomposes the entire undergraduate graduation design link into each link of the university from an application point of view. On the one hand, it reduces the difficulty of topic selection, which enlightens students to choose the topic they are interested in, so as to improve the quality of the completion of the undergraduate graduation project. On the other hand, it is also combined with specific scientific research projects, which can also improve scientific research projects to a certain extent.

\section{REFERENCES}

[1] $\mathrm{Wu}$ Lizhi, Chen Xiaolan. Undergraduate thesis writing guide $[\mathrm{M}]$. Beijing: Tsinghua University Press, 2011.

[2] [2] Zhao Shuheng, Li Panpan, Tao Hongge, Jing Yanyan. Some thoughts on guiding the graduation design (thesis) of engineering college students[J]. Education Teaching Forum, 2019 (31): 207-209.

[3] [3] Gao Yanli. Thoughts and Actions on Improving the Quality of Graduation Design
Thesis[J]. Education Teaching Forum, 2019 (9): 219-220.

[4] Zheng Lina. Dong Xuelian's Thoughts on Several Questions about Undergraduate Graduation Thesis[J]. Education Teaching Forum, 2019 (27): 34-35.

[5] Wu Junhua, Chen Xinglin, Ge Fei. Select topics from scientific research projects to improve the quality of undergraduate graduation design[J]. Science and Technology, Economy, Market, 2015 (3): 209-210.

[6] Hao Yongmei, Ge Xiukun, Shao Hui, etc. Engineering Innovation for Local University Engineering Students Ways to Cultivate New Ability $[\mathrm{J}]$. Journal of Changzhou University (Social Science Edition), 2011 (2).

[7] Chen Kesong, Wang Ling, Zhang Biao. Process optimization of undergraduate graduation design[J]. Reality Experimental Science and Technology, 2017 (6).

[8] Xiao Weicai. The exploration of the teaching model of the integration of theoretical teaching and practical teaching Cable and Practice [J]. Laboratory Research and Exploration, 2011 (4).

[9] Lv Shanhui, Lv Xin. TRIZ Theory in the Cultivation of College Students' Innovation and Entrepreneurship Ability Applied Research in Chinese [J]. Contemporary Educational Practice and Teaching Research, 2017 (2).

[10] Huang Haiyan, Xu Zhidan, Yang Fuyuan, etc. Learning based on in-depth school-enterprise cooperation Research on Practice Education Mode of Bioengineering[J]. Experimental Technology and Management, 2019 (4). 